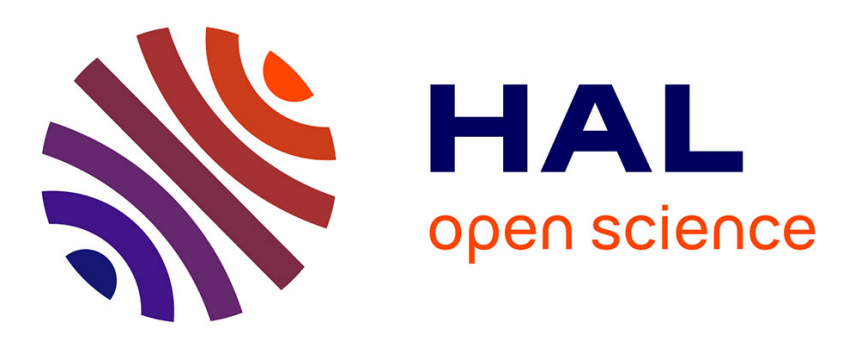

\title{
The legal status of religious minorities in the medieval Mediterranean world: a comparative study
}

John Tolan

\section{To cite this version:}

John Tolan. The legal status of religious minorities in the medieval Mediterranean world: a comparative study. Borgolte, Michael. Hybride Kulturen im mittelalterlichen Europa: Vorträge und Workshops einter internationalen Frühlingsschule/Hybrid Cultures in Medieval Europe: Papers and Workshops of in International Spring School, Akademie Verlag, pp.141-149, 2010, Europa im Mittelalter. hal-00639262

\section{HAL Id: hal-00639262 https://hal.science/hal-00639262}

Submitted on 22 Nov 2011

HAL is a multi-disciplinary open access archive for the deposit and dissemination of scientific research documents, whether they are published or not. The documents may come from teaching and research institutions in France or abroad, or from public or private research centers.
L'archive ouverte pluridisciplinaire HAL, est destinée au dépôt et à la diffusion de documents scientifiques de niveau recherche, publiés ou non, émanant des établissements d'enseignement et de recherche français ou étrangers, des laboratoires publics ou privés. 


\title{
The legal status of religious minorities in the medieval Mediterranean
} world: a comparative study

\author{
John TOLAN, Université de Nantes \\ John.tolan@univ-nantes.fr
}

[originally published in Michael Borgolte \& Bernd Schneidmüller, eds., Hybride Kulturen im mittelalterlichen Europa: Vorträge und Workshops einter internationalen Frühlingsschule/Hybrid Cultures in Medieval Europe: Papers and Workshops of in International Spring School (Berlin: Akademie Verlag, 2010), 141-49.]

\begin{abstract}
Throughout the Mediterranean world in the Middle ages, Jews, Christians and Muslims interacted in streets and in marketplaces, shared meals, undertook joint economic ventures, traveled together. These interactions were, in theory, governed by a host of legal strictures. Yet the clerical elites who were often the guarantors of these religious/legal traditions often reacted with realism and pragmatism, adapting the seemingly rigid constraints of religious law to specific needs. Two examples are used to illustrate this, from the writings of twelfth-century ifriqiyan mufti al-Māzarī and thirteenth-century canonist Raymond of Penyafort.
\end{abstract}

Keywords: dhimmis, religious minorities, history of religion, history of law

The Research leading to this publication has received funding from the European Research Council under the European Union's Seventh Framework Progamme (FP7/2007-2013) /ERC project RELMIN grant agreement $n^{\circ}$ [249416]. See www.relmin.eu .

Résumé: Partout dans le monde méditerranéen médiéval, juifs, chrétiens et musulmans se côtoyaient dans les rues et dans les marchés, partagèrent des repas, entreprirent des affaires commerciales, voyagèrent ensemble. Ces interactions étaient en théorie réglées par une législation importante. Mais les élites cléricales qui veillaient à l'application de ces traditions religieuses et légales surent, souvent, réagir avec pragmatisme, adaptant le carcan apparement rigide de la lois religieuses aux exigences de la situation. On se penchera sur deux exemples, pris des écrits du mufti ifriqiyen al-Māzarī au XIIe siècle et du canoniste Raymond de Penyafort au XIIIe.

Mots clefs: Tolérance, dhimmis, antisémitisme, minorités religieuses, histoire des religions, histoire du droit

Mots clefs: dhimmis, 
minorités religieuses, histoire des religions, histoire du droit

La recherche qui a abouti à cette publication a été financée par le Conseil européen de la recherche sous le septième programme cadre de l'Union eruopéenne (FP7/2007-2013) / projet ERC RELMIN contrat $\mathrm{n}^{\circ}[249416]$. Voir www.relmin.eu .

From Baghdad to Barcelona, Jews, Christians and Muslims rubbed shoulders in streets and in marketplaces, shared meals, undertook joint economic ventures, traveled together, etc. Each of the three major religions, moreover, was split into a plethora of divisions and sects: Jews into Karaites and Rabbanites; Christians into orthodox, Melkites, Jacobites, Catholics, Nestorians; Muslims knew not only the Shiite/Sunni division but also the varying influence of the four Madhabs.

Throughout the medieval oikoumene, rules regulated the relations between members of these different groups. While one religion was associated with the ruler, his dynasty, and his religiously-based political ideology, deviant groups might be banned altogether; but in general, one or more religious groups were allowed to exist as minorities within the dominant society. Their rights to practice their religion were acknowledged, but often they did not enjoy the same rights and privileges as the majority. This is the situation of dhimmi, protected but subordinated Jews and Christians, throughout the Muslim world in the Middle Ages. It is also the situation of Jews in Byzantium and much of Western Europe, and of Muslims in the Christian kingdoms of Spain, in Sicily, and in the Latin Levant.

Muslim and Christian rulers of the Middle Ages claimed that their power emanated from God; the majority religion was closely associated with ideologies of power (of caliphs, emperors, popes, kings). These ideologies clearly express the religious inferiority of those who do not profess the majority faith, inferiority which is to be reflected in social inferiority. Yet we also find clear religious and legal injunctions concerning the toleration of members of rival religions within these societies.

I am initiating a comparative, collaborative study on legal status of these religious minorities in the medieval Mediterranean world. Today I will simply take a brief look at a rich and complicated subject. I will first sketch overview of the subject, with a brief introduction to essential texts and a few recent important studies, looking primarily at the place that majority societies accorded to religious majority. I will then present two examples of the legal point of view of the minorities themselves; at how 
jurists of those minority communities dealt with legal/religious problems posed by their minority status. One example involves Muslims living in Norman Sicily in the 12th century, the other European Christians living in Tunis in the 13th.

First, then, it will be useful to make a brief overview of the subject, in which I will not at all try to be exhaustive or comprehensive but will look briefly at three aspects of the question: the status of: Jews in Justinian's Rome, of Dhimmis in Muslim societies, and of Jews and Muslims in Latin Europe.

Let me start with a brief look at the role accorded to Jews in the legislation of Justinian. Justinian, of course, played a key role in the codification and rationalization of Roman law. He left a series of text which were to have a profound influence on the legal systems of Byzantium and of Latin Europe. The ninth titulus of his Codex Iustinianus contains a series of laws concerning Jews, establishing both limitations of their civic rights and limited protections. ${ }^{1}$ The Codex prohibits Jews from attacking or insulting converts from Judaism to Christianity. Jews may not marry Christians; nor may they blaspheme or insult Christianity or engage in defamatory acts such as burning of crucifixes. They may not circumcise Christians or proselytize. Jews are prohibited from public office and are prohibited from building new synagogues (though they may repair existing ones).

Yet the Codex also guarantees certain rights and protections to Jews. Soldiers may not be billeted in synagogues; no one may summon a Jew to court on the Sabbath; Jews are protected from insult and injury on the part of Christians. All this is in accord with much of the patristic theology concerning the role of Jews in Christian society, expressed for example by Augustine: Jews must be tolerated (preserve Hebrew scriptures; conversion at the end of time), but their "heads must be bowed".

${ }^{1}$ Codex lustinianus, title ix: Concerning Jews and the worshippers of the heavens [translation by S. Scott, The Civil Law (17 vols.; Cincinnati: The Central Trust Company, 1932), http://www.constitution.org/sps/sps12.htm ] ; see Catherine Brewer, "The Status of the Jews in Roman Legislation: The Reign of Justinian 527-565 CE," European Judaism 38 (2005), 127-139. 
Several passages in the Qur'ān discuss the attitudes that Muslims should have towards ahl al-Kitab, people of the book (Jews and Christians). They may be forced to submit to Muslim authority and pay a poll tax (jizya), but must not be converted by force. Through their submission, they obtain protection (dhimma, hence the term dhimmi, "protected"). Yet our knowledge is based mostly on texts written centuries after the Muslim conquests: it is hard to know much about to what extent early practice complied with later theory. One rare example of a conquest-era document on the submission of Christians to Muslim rule is the so-called Treaty of Tudmir, named for a Spanish Visigothic lord (Theodimir): the Muslim governor 'Abd al-'AzīZ ibn Musa ibn Nusair recognizes Theodimir's authority over a series of towns in southeastern Spain, and Theodimir agrees to acknowledge 'Abd al-'Aziz's suzerainty and to pay specific amounts of tribute per head. ${ }^{2}$

The so-called "Pact of Umar" purports to be by "Umar ibn al-Khattab (2nd caliph), but is no doubt later, perhaps from the eighth century or even as late at the twelfth. It is at any rate first found in Al-Turtushi's Siraj al-Muluk, in the early twelfth century. It is in the form of a letter by conquered Christians to the caliph; they promise not to do a whole list of things: build new churches, ring church bells too loudly, insult Muslims, ride on horseback, dress like Muslims, etc. Many other texts deal with the place of Jews \& Christians in Muslim society: Hisba (municipal codes) in Andalus and the Maghreb, collections of fatwās (juridical consultations), etc. The sources tend to be late and have provoked differences of opinion among specialists. Moreover, a number of books on the subject are sharply biased, meant to prove either that Muslims are intolerant fanatics who persecute helpless Jews \& Christians; or on the contrary, that Islam is a religion of tolerance and that medieval Jews, Christians and Muslims lived in harmony: trading, translating, and partying. The more nuanced and documented studies (like those cited here, note 2) show that in

\footnotetext{
2 See Khaled Abou EI Fadl, "Islamic Law and Muslim Minorities: The Juristic Discourse on Muslim Minorities from the Second/Eighth to the Eleventh/Seventeenth Centuries," Islamic Law and Society 1 (1994), 141-187; Antoine Fattal, Le statut légal des non-musulmans en pays d'Islam. Beirut: Dar el-Machreq, 1995; Yohannan Friedmann, Tolerance and Coercion in Islam: Interfaith Relations in the Muslim Tradition. Cambridge: Cambridge University Press, 2003.
} 
fact generalization is difficult, and that legal texts tend to reflect each author's take on a situation that is often local and particular.

What about Jews and Muslims living in Latin Europe in the twelfth and thirteenth centuries ${ }^{3}$ The twelfth century sees several important trends in European legal history: first, the rediscovery (actually in 11th century) of Justinian and a burgeoning interest in Roman law (increasingly studied, particularly in Bologna); second a corresponding resurgence in canon law, seen in the Decretum (mid-twelfth century), traditionally attributed to Gratian, and in the Gregory IX's Decretales (1230s). These texts, in continuation with Justinian's Codex, provide a protected but restricted place in society for Jews. Increasingly, the Muslims (pagani, Sarraceni) are given the same legal status as Jews.

On the whole, these laws prohibit marriage and sexual relation between Christians and non-Christians. It is prohibited for Jews and Muslims to own Christian slaves or to have any position of power or authority over Christians. While this is the theory, this does not mean that all the laws were respected in practice. In Spain, for example, royal law prohibits sexual relations between Christians \& non-Christians; municipal laws (fueros) legislate on the offspring of Christian men and their Muslim slave girls.

While the history of (majority) law dictating the place of the (minority) community has been studied, much less work has been done on the legal point of view of the minority community on their subordinate status. This is the topic I wish to explore, through two specific examples, in the remainder of my time today.

3 See Henri Gilles, "Législation et doctrine canoniques sur les Sarrasins", in Cahiers de Fanjeaux, 18, 1983, Islam et Chrétiens du Midi, p. 195-213 ; Benjamin Kedar, "De ludeis et Sarracenis : On the Categorization of Muslims in Medieval Canon Law," in Franks in the Levant, 11th to 14th centuries (Aldershot, Hampshire: Variorum, 1993); James Muldoon, Popes, Lawyers, and Infidels: The Church and the Non-Christian World, 1250-1550 (Philadelphia: University of Pennsylvania Press, 1979); James Powell, ed., Muslims under Latin Rule, 1100-1300 (Princeton: Princeton University Press, 1990); John Tolan, Saracens: Islam in the Medieval European Imagination (New York: Columbia University Press, 2002). 
My first example is a Muslim mufti's view on the legality of Muslim residence in Norman Siclily. The Normans of southern Italy conquered Sicily over a period of thirty years, from roughly 1061 to 1091, in part through alliances with Muslim qaids. Twelfth-century Norman Sicily thus has large numbers of Muslims: mostly peasants and soldiers, but also some fairly prominent in the entourage of the king. One of the most interesting testimonies to the life of these Sicilian Muslims is that of Andalusian traveler Ibn Jubayr, who visited the island in 1185: an ambivalent picture, noting both the respect and tolerance afforded to Sicilian Muslims but also humiliations and pressures to convert. ${ }^{4}$

The document that interests me here also sheds light on the role of Muslims in Sicily. It is a fatwā: a judicial consultation, one of thousands of such documents preserved from the medieval Maghreb. ${ }^{5}$ Here is how such consultation works: one poses a question to a mufti, who gives his opinion, citing religious/legal texts (including legal opinions of earlier scholars). In the Maghreb, the Malikite madhhab (legal school) dominates. Al-Wansharīsī (16th century) put together a huge encyclopedic collection of fatwās, showing their continuing relevance and importance: most of them come from Andalusian and Maghribi muftis of the middle ages. He includes a number of fatwās from al-Māzarî who, he tells us, was active in Mahdia (Tunisia) and who died in 1141 . This is all we know about his biography, though his kunya, Māzarì , would indicate that he (or at least his family) was from the

4I bn Jubayr, Rihla, William Wright \& Michael Johan de Goeje, eds., The travels of Ibn Jubayr edited from a Manuscript in the University Library of Leyde (Leiden: Brill, 1907; reprint Frankfurt am Main : Institute for the history of Arabic-Science, 1994); Roland Broadhurst, trans., The Travels of Ibn Jubayr (London: 1952).

5On this fatwā, see Sarah Davis-Secord, "Muslims in Norman Sicily: The Evidence of Imām al-Māzarī’s Fatwās", Mediterranean Studies 16 (2007), 46-66; Abdel Majid Turki, "Consultation juridique d'al-Imam al-Māzarî sur le cas des musulmans vivant en Sicile sous l'autorité des Normands," Mélanges de I'Université Saint-Joseph 50 :2 (1984), 691-704; John Tolan, Histoire médiévale: Les Relations entre les pays d'Islam et le monde latin du milieu du Xème siècle au milieu du XIIlème siècle (Paris: Bréal, 2000), 152-56. 
town of Mazara in Sicily-which may in part explain his interest in the question posed to him.

The fatwā opens with the statement that someone (typically, we do not know who) has come to the mufti with a precise religious/legal question: "Concerning judgments coming from Sicily, pronounced by its qādī: should these judgments be considered legitimate or should they be rejected? And what of the depositions of its witnesses, given that these things are imposed by necessity and that it is impossible to know if their authors live under the authority of infidels voluntarily or under constraint?" In his response, al-Māzarī divides this into two questions: The first concerns the qādī and his opinions and their integrity, given that he is residing in enemy territory (dār al-harb) and under the authority of infidels, which, he says, is forbidden. The second question concerns his investiture, since "he is invested by the infidel". In other words, how can Sicilian Muslims submit to the authority of a qādī who is appointed by the Christian king of Sicily?

The problem posed, then, is that of the very legality of Muslim communities in Norman Sicily_and, a priori, in any realm ruled by a non-Muslim. Al-Mazarī begins with statement that residing in non-Muslim territory (dār al-harb) is forbidden. This, however, is the opening, and not the conclusion, of the legal inquiry: while this principle was widely recognized in theory, legal opinion on whether Muslims could live in non-Muslim lands was divided: some muftis argued that Muslims should make every effort to leave a territory as soon as it came under the control of an infidel ruler; others argued on the contrary that it was meritorious to stay on as long as possible, providing that one was free to practice Islam, in order to keep Islam alive in the territory. ${ }^{6}$

In addressing his first question, al-Māzarī' speculates as to why a Muslim might live in infidel territory. If he lives there "out of necessity" (which seems to include both physical compulsion and economic imperative), "there is nothing that lessens his integrity". This is also true if he resides there out of his own choice and, unaware that his residence is illegal, believes that it is permitted. "For," says the mufti, "he is not obliged to know this piece of jurisprudence; hence his ignorance would not at all compromise his integrity." Al-Māzarī also says that one can justify his residence in the dār al-harb through the hope that the territory will one day be returned to Islam.

'Abou El Fadl, "Islamic Law and Muslim Minorities". 
One who hopes to "guide the infidels on the path of truth" or steer them clear of heresy is also allowed to stay on without compromising his integrity. He cites Malikite jurist Al-Bāqillānī (d. 1012) who judged that it is permissible to penetrate into enemy territory in order to free a prisoner. Even one who is simply ignorant of the prohibition to live in non-Muslim territory is excused, as is one who misunderstands or misinterprets the law.

This is a prime example of ljtihad, reinterpretation of Muslim law to fit changing circumstances. Al-Māzarī' begins with the uncontested premise that residence in dār al-harb is strictly forbidden, then lists numerous exceptions, to the point where a Muslim who merely hopes that Sicily may one day return to the Muslim fold is permitted to live on in Christian territory. Only if one "willfully disobeys the law or deliberately avoids any effort to interpret it" is he blamable. While expressing some doubt about the legitimacy of traveling to non-Muslim territory for commerce, he concludes that "The principle must be to tolerate the personal reasons of anyone of apparent probity, even if the reasons for his staying in enemy territory may appear suspicious. The great majority of the above hypotheses plead for tolerance and it is not possible to reduce these possible motives to one explanation, unless evidence proves that his stay had no compelling reason and was effected deliberately."

Al-Māzarī' then addresses his second point, the legitimacy of the qādī and other officials who, in Norman Sicily, were named by the Christian King or his officers. "It is clear", he says "that they must protect their charges", citing the Mudawwana, a compendium of Malikite legal opinions by the Sahnûn (d. 854), jurist from Qayrawan. Sahnûn had affirmed the legality of any interim assured by the officers of any place in absence of the prince [sultān], in order that they may continue to judge urgent cases. Al-Māzarī' concludes: "The investiture accorded by the infidel on this upright qādī, either in order to judge an urgent affair or to respond to the needs of his clients, does not compromise in the least his judgments, which maintain their legitimacy, just as if he had been invested by a Muslim prince." In other words, he considers that Sicily is in a state of interim: it once had a legal Muslim ruler; it would have one again some day: the current non-Muslim prince cannot be considered legal or legitimate from the standpoint of a medieval Muslim jurist. ${ }^{7}$ Yet in this state of interim, Muslim judges

\footnotetext{
'Davis-Secord (op. cit.) says that al-Māzarī' here recognizes the legitimacy of the rule of the Sicilian king; he in fact recognizes no such legitimacy.
} 
and other officials must continue to serve their flock. It is their uprightness, the justice emanating from their decisions, which confers authority upon them: the fact that they were invested by an infidel (hence illegitimate) ruler neither lessens nor augments their legitimate authority.

This fatwā shows the mind of a mufti at work, attentive to the hopes and needs of his contemporaries and adapting legal traditions to suit the conditions of his flock. This is, of course, the opinion of one mufti; others took a much harder line and insisted that all Muslims should leave a territory conquered by infidels. Others took an intermediate position, recognizing some (but not all) of the mitigating circumstances elucidated by al-Māzarì'. ${ }^{8}$ The legal traditions of Islam, while clearly grounded in the canonical texts of Qur'ān and Hadīth, are wide enough and flexible enough to allow for diverse sensibilities and for creative adaptations to new situations.

We will find a similar creative adaptation of traditional religious jurisprudence in our second example, a text concerning Latin Christians living in Muslim lands-in Tunis in the thirteenth century. On January 19, 1235, Raymond of Penyafort, major penitentiary to Pope Gregory IX, wrote a letter to the Dominican Prior and the Franciscan Minister "in the kingdom of Tunis". These two friars had written to the pope with forty quite specific questions concerning problems that they faced in serving the Christian community of Tunis; the response is written by Raymond at the pope's behest: a series of forty short articles, the Responsiones ad dubitabilia circa communicationem christianorum cum sarracenis. Each article contains, first, a question that the mendicants in Tunis had posed to the Pope, then the pope's response, as transcribed by Raymond. The questions involved concern the

\footnotetext{
8See Abou EI Fadl, "Islamic Law and Muslim Minorities"; Kathryn Miller, Guardians of
} Islam: Religious Authority and Muslim Communities of Late Medieval Spain (New York: Columbia University Press, 2008). 
sinfulness (or not) of everything from selling iron nails to Muslims to surreptitiously baptizing their children. 9

This text offers a unique glimpse of the workings of the Latin Christian community in Tunis and of papal responses to the problems posed by Christians living in Muslim lands. In the first place, it provides documentation of trade practices of European (principally Italian and Catalan) merchants in Ifrīgiya (roughly what it now Tunisia). In this it complements other important documentation: the treaties (in Latin and Arabic) between European and Maghribi rulers; and the great number of trade documents (primarily contracts) in the archives of Pisa, Genoa, Venice, Barcelona, and other cities. What is particularly intriguing about this document is that it places these issues clearly in the framework of papal prohibitions against certain kinds of trade with Muslims: one sees some merchants openly flouting these prohibitions, others trying to respect them or making excuses for their non-respect of them.

Moreover, the Responsiones give us a unique glimpse at the richness and complexity of the European catholic community in Tunis that the friars seek to serve: not only the Italian and Catalan Merchants, but also mercenaries, crusaders, fugitives, captives, or pilgrims on their way to Jerusalem. We find, in particular, a number of marginal persons whose existence is seldom registered in other contemporary documents, in Arabic or Latin: renegades, slaves, converts, mixed couples.

I will not here give a detailed analysis of this document, much of which is about the legitimacy of certain kinds of trade (since the third and fourth Lateran councils, in 1179 and 1215, had banned trade with "Saracens" in weapons, iron and wood). I

\footnotetext{
${ }^{9}$ Responsiones ad dubitabilia circa communicationem christianorum cum sarracenis, in Raymond of Penyafort, Summae, 3 vols., in Xavier Ochoa and Aloysius Diez, eds., Universa Bibliotheca luris I (Rome, 1976-78) 3: 1024-36; what follows is in part based on Tolan, "Taking Gratian to Africa: Raymond de Penyafort's legal advice to the Dominicans and Franciscans in Tunis," in Adnan Husain \& Katherine Fleming, eds., A Faithful Sea: The Religious Cultures of the Mediterranean, 1200-1700 (Oxford: One World, 2007), 47-63.
} 
instead want to focus on several paragraphs having to do with problems of conversion and family.

In their eighth question, the friars observe disapprovingly that some Christians obligant vel impignorant viros vel feminas de familiis suis saracenis, necessitate compulsi. The words obligare and impignorare both have legal meanings of " pawn » or "mortgage », so this passage could be translated as "they pawn or mortgage to Saracens men or women from among their servants". What seems to be happening here is that Christians-especially, but not exclusively, knights (milites)_in debt (necessitate compulsi) are handing over to Muslims Christian men and women from among their familiis ("servants") as guarantees for their debts or other legal (perhaps military) obligations. What bothers the friars is not the pawning of humans, but the spiritual risk involved in handing over Christians to Muslims for indefinite periods of time (one imagines that these persons became permanent possessions of their new lords in case of default on the debtor's obligations). Many of them, particularly the young (pueri vel puellae), end up converting to Islam: fiunt postmodum sarraceni. The pope's response is that such practice is mortal sin, but does not incur excommunication.

In general, of course, conversion in Muslim Tunis is envisioned in only one direction: to Islam. One passage refers to Christians who in "fear of the Saracens" participate in secret night-time services; these may be nominal Muslims who have surreptitiously returned to Christianity. Only one passage (โ9) deals with the actual baptism of Muslims. Some Christian servants or slaves of Muslims took care of Muslim children. They asked the Friars whether they could and should secretly baptize these children: if they then died before the age of discretion, they would be saved. The pope responds that they should be baptized. We may presume, then, that a number of Muslim children of 13th-century Tunis were secretly baptized by their Christian nannies.

A further set of problems is posed by conversions of Christians to Islam.

One of the friars' questions $(\mathbb{\$ 1 0})$ involves those who were Christians and subsequently converted to Islam postmodum facti sunt sarraceni. Some converted when they were young, some adult; some slave, some free: many of them converted, say the friars, largely because they were ignorant concerning the articles of the faith. Such apostasy, in Christian Europe, is illegal-potentially a capital crime. But of course in Muslim Tunis, there is no question of punishing them, as they are beyond 
the reach of Christian princes and indeed of spiritual penalties such as excommunication (since they have voluntarily removed themselves from communion with the Church, according to Gratian's Decretum). The concern here is for their relatives who have remained Christian. According to Canon law, Christians ought to shun the company of heretics; exceptions are allowed for those who seek to bring them back to the Catholic fold. Yet the friars realize that if they try to prohibit Christians in Tunis from maintaining contact with their Muslim relatives, they will have little luck, and will most likely only push them to apostatize as well. "It seems to us that they cannot easily abstain from frequenting the above-mentioned people, either because they love them according to the flesh, as their children, or because they receive food from them." The pope answers that they may frequent these Muslim causa correctionis vel necessitatis - in other words, either in order to try to bring them back into the Christian fold or for material necessity. By applying Gratian's legislation concerning heretics to Muslims, Raymond and Gregory place Islam-in legal and practical terms-in the category of heresy. This is in line with much contemporary theological reflection on Islam, particularly the work of Latin Christian polemists against Islam in the twelfth and thirteenth centuries.

The following section ( $\mathbb{T} 11$ ) deals with the problem of mixed marriages. While it is not legal for a Christian to marry a non-Christian, the question here is what happens when one member of a married Christian couple labatur in haeresim, slides into heresy-in other words (in this context) converts to Islam (here again, Islam is treated as heresy). Gratian echoes earlier church legislation in strictly prohibiting marriage between Christians and non-Christians. Yet exceptions are made in cases of conversion: Causa 28 of the Decretum deals with the case of a married infidelis who converts to Christianity and whose spouse remains infidelis. Gratian affirms that it is permitted for the new Christian to separate from his non-Christian spouse, but also that she or he may remain married if she or he so wishes. The key distinction here is to know whether the now Christian member of the couple can remain married to the infidel spouse without contumelia creatoris "insult to the creator". This is a direct reference to Decretum c28 q2 c2: when the non-Christian spouse hates Christianity, and is guilty of insult to the creator, the Christian spouse may not only separate from the infidel, but may marry anew. The bible prohibits divorce; separation or annulment is allowed on specific grounds, including consanguinity and adultery. The Decretum affirms that contumelia creatoris is a sort of spiritual 
adultery, far worse than the mere physical kind, and that it is therefore grounds for separation and annulment of marriage. Raymond and the pope apply Gratian's ruling concerning conversion of the marriage of a convert to Christianity to the case of mixed couples where a Christian has converted to Islam. Again, Raymond and the pope are showing a good deal of flexibility, adapting their response to the situation of Christians living in Muslim Tunis: to do otherwise would make their lives more difficult than they already are and encourage more of them to turn to Islam.

Both Al-Māzarī’s fatwā and Raymond's Responsiones show that medieval jurists could react with realism and pragmatism, adapting the seemingly rigid constraints of religious law to specific needs. To avoid the trap of essentialism (either a lachrymose view of interfaith relations or on the contrary a portrait of sunny, tolerant convivencia), more close comparative research needs to be done in the field of interreligious relations in the Middle Ages.

John Tolan, Université de Nantes

This publication is part of the research project RELMIN “"'The Legal Status of Religious Minorities in the EuroMediterranean World $\left(5^{\text {th }}-15^{\text {th }}\right.$ centuries $)$ "

The research leading to this publication has received funding from the European Research Council under the European Union's Seventh Framework Progamme (FP7/2007-2013) /ERC grant agreement n²49416. 